Ann. Génét. Sél. anim., I978, 10 (2), 27I-274.

Note

\title{
The C-banding pattern of the Egyptian Water Buffalo (Bubalus bubalis)
}

\author{
E. P. CRIBIU and A. OBEIDAH $\left({ }^{*}\right)$ \\ with the technical assistance of Jeannine BOscher \\ I.aboratoire de Cytogénétique U.N.C.E.I.A.-I.N.R.A., \\ Centre National de Recherches Zootechniques \\ $7835^{\circ}$ Jouy-en-Josas, France \\ $\left(^{*}\right)$ Animal Breeding Department \\ Faculty of A griculture \\ Cairo University \\ GIZA Egypt
}

\section{Summary}

The diploid chromosome number of the Egyptian Water Buffalo is 50 of which Io are metaand submetacentric and the remainder are acrocentric including the $\mathrm{X}$ and $\mathrm{Y}$. Pericentromeric constitutive heterochromatin is apparently absent in the meta and submetacentric chromosomes except for pairs 2,3 and 4. All the acrocentric autosomes and the sex chromosomes have pericentromeric constitutive heterochromatin.

The karyotype of the Egyptian Water Buffalo (Bubalus bubalis) has been reported by DE HoNDT and GHANAM (I97I). The diploid number found was 50 of which 5 pairs were meta-and submetacentric and 20 pairs were acrocentric including the $\mathrm{X}$ and $\mathrm{Y}$ chromosome.

The present work was undertaken to establish the C-banding pattern of the Egyptian Water Buffalo.

Thirty animals (20 males and Io females) from northern Egypt were studied. Blood samples were obtained from the jugular vein for leucocyte cultures. Chromosome studies were carried out on leucocyte cultures according to the method of DE Grouchy et al. (I964). 
Following storage of the slide for a month, C-banding was achieved by a modification of the technique of SUMNER (I972). Slides were incubated for I $5 \mathrm{mn}$ in saturated aqueous solution of barium hydroxide at $50{ }^{\circ} \mathrm{C}$. They were, then, rinsed in distilled water and placed in $2 \times \mathrm{SSC}(0.3 \mathrm{M}$ sodium chloride and $0.03 \mathrm{M}$ tri-sodium citrate, $\mathrm{pH} 7.2$ ) for $2 \mathrm{~h}$ at $60^{\circ} \mathrm{C}$. The slides were then washed in distilled water and stained for $6 \mathrm{mn}$ in $4 \mathrm{p}$. Ioo Giemsa. Following which microscopic examinations were conducted.

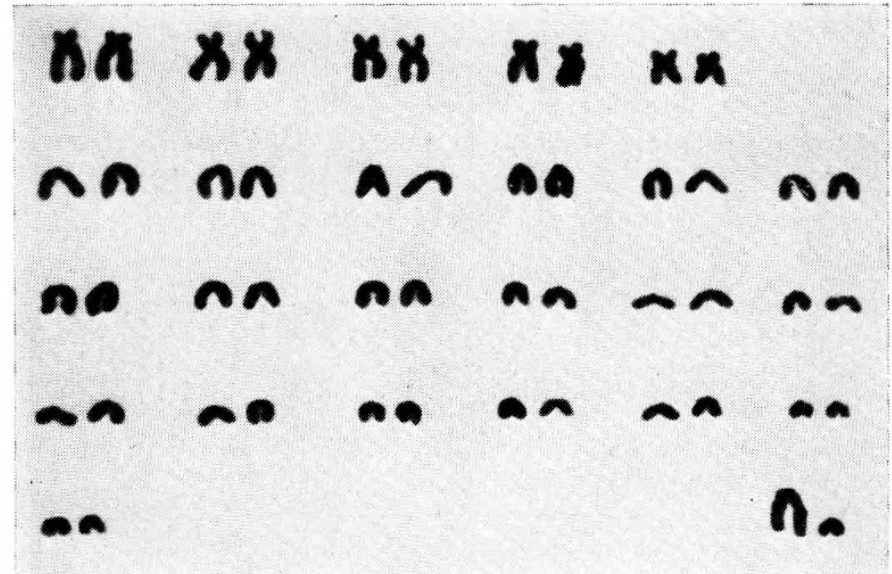

FIG. I. - Karyotype of male Egyptian Water Buffalo

Caryotype mâle du Buffe d'eau égyptien

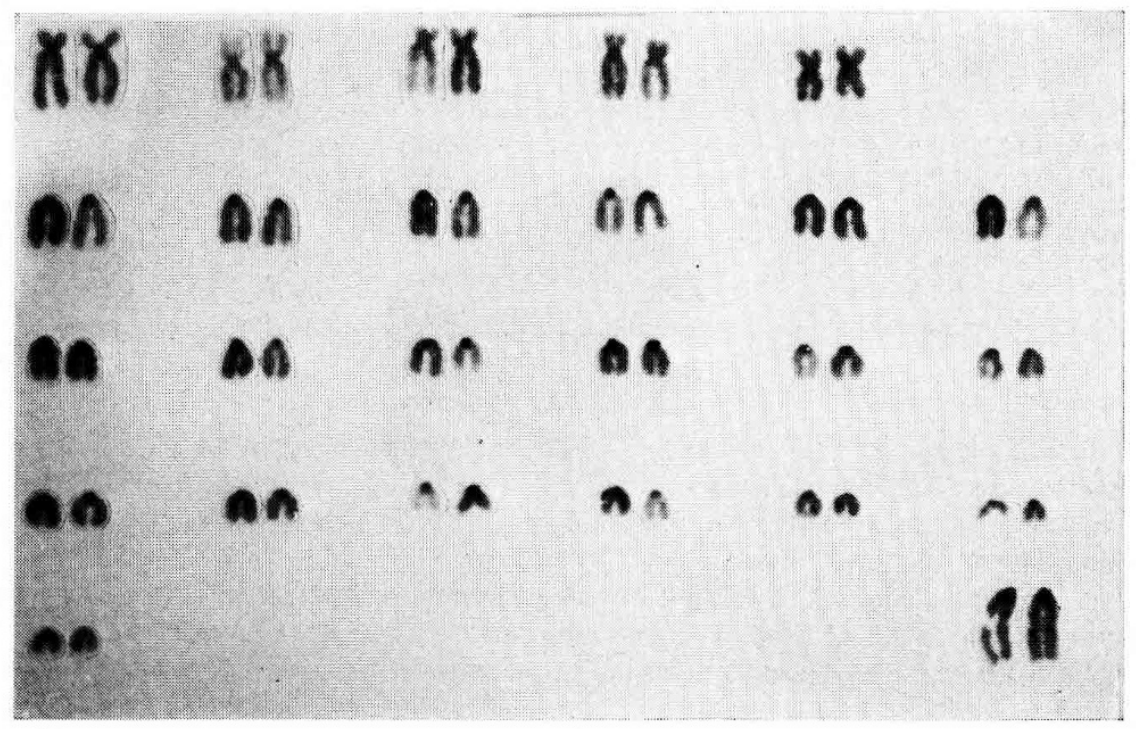

FIG. 2. - The C-banding karyotype of female Egyptian Water buffalo Le caryotype en bande $C d u$ Buffle d'eau égyptien 
The diploid chromosome number of this sample of Egyptian Water Buffalo was found to be 50 of which 5 pairs were meta- and submetacentric and 20 pairs were acrocentric including the 2 sex chromosomes. The $\mathrm{X}$ chromosome was observed to be the largest acrocentric and the $\mathrm{Y}$ one of the smallest (fig. I).

The distribution of constitutive heterochromatin (C-banding) in the genome can be described as follows : constitutive heterochromatin is apparently absent in the meta and submetacentric pairs numbered $I$ and 5 but a slight suggestion

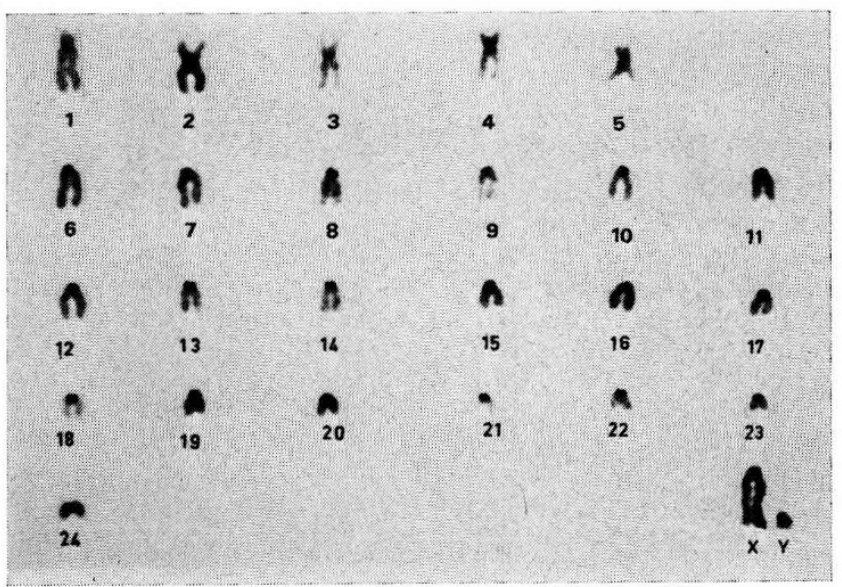

FIG. 3. - The C-banding karyotype of male Egyptian Water Buffalo

(One chromosome of each pair is put. The numbers arbitrarly assigned are given to let the understanding of the text.)

\section{Le caryotype du Buffle d'eau égyptien en bande $C$}

(Un chromosome de chaque paire a été représenté et les numéros affectés à chacun ont été donnés pour permettre une meilleure compréhension du texte).

of pericentromeric heterochromatin can be seen in pairs 2, 3 and 4 . All the acrocentric chromosomes including the $\mathrm{X}$ and $\mathrm{Y}$ have a densely stained centromeric region (fig. 2 and 3 ).

These observations indicate that the karyotype of Egyptian Water Buffalo is similar to that of the Asian River Buffalo (Murrah Buffalo) described by FISCHER and UlbRICH (I968). The same results than these of SHEURManN et al. (I974) and ROMMELT (I976) studing the C-banding pattern of the Ceylan Water Buffalo and Malaysian Murrah Buffalo were found here except for the $\mathrm{Y}$ chromosome which they described as being darkly stained only in its distal area.

The origin of the Buffalo in Egypt was reviewed by CockrILI, (I974). They were introduced from India, Iran and Iraq shortly after the arab invasion, about the middle of the seventh century. The present finding that the Egyptian Water Buffalo has a similar C-banding karyotype to that of SCHEURMANN's animals from Ceylan supports this historical fact. 


\section{Acknowledgments}

We thank Dr C. P. PoPEScu (Laboratoire de Cytogénétique U.N.C.E.I.A.-I.N.R.A., C.N.R.Z. Jouy-en-Josas, France), Dr W. E. HowELI, (Department of Animal and Poultry Science University of Saskatchewan, Saskatoon, Canada), Dr N. S. FEchHEIMER (Animal Reproduction Research and Teaching Center, Ohio State University Columbus, Ohio, USA) and Dr G. W. RIEck (Institut für Zuchthygiene und veterinarmedizinische Genetik-Justus-Liebig-Universität-Giessen, R.F.A.) for helpful discussions and critical reviews of the manuscript.

\section{Résumé}

\section{Caryotype du Buffle d'eau égyptien par les bandes $C$}

Le Buffle d'eau égyptien possède 50 chromosomes dont to méta et submétacentriques et $4^{\circ}$ acrocentriques. Les gonosomes $\mathrm{X}$ et $\mathrm{Y}$ sont acrocentriques. L'hétérochromatine constitutive péricentromérique est apparemment absente sur les chromosomes méta- et submétacentriques à l'exception des paires 2,3 et 4 . Tous les autosomes acrocentriques ainsi que les deux chromosomes sexuels possèdent de l'hétérochromatine constitutive péricentromérique.

\section{References}

Cockril, , W. R., I974. The husbandry and health of the domestic buffalo. Food and agriculture organization of the United Nations, Rome.

De Grouchy J., Roubin M., Passage E., I964. Microtechnique pour l'étude des chromosomes humains à partir d'une culture de leucocytes sanguins. Ann. Génét., 7, 45 .

De Hond' H. A., Ghanam S. A., I97I. Cytogenetic studies of the Egyptian Water Buffalo (Bubalus bubalis). Z. Tievzücht. Züchtgs Biol., 88, 64-88.

Fischer H., UrbRICH F., I968. Chromosomes of the Murrah Buffalo and its Crossbreds with the Asiatic Swamp Buffalo (Bubalus bubalis). Z. Tierzücht. Züchtgs Biol., 84, IIo-II4.

RoMMELr C., I976. Karyotypidentifikation mit Hilfe der G- und C-Bandentecknik beim Sumpf und Murrah-Büffel - Erlangung des Doktorgrades bei dem Fachbereich Veterinärmedizin und Tierzucht der Justus-Liebig-Universität zu Giessen.

Scheurmann E., Wiesner R., Fischer H., JAINUdeEN M. R., 1974. Karyotyp, C-Banden und Identifizierung der Geschlechtschromessomen des Ceylonesischen Wasserbüffels (Bubalus bubalis). Giessener Beitr. Erbpath. Zuchthyg., 6, I-7.

SumNer A. T., I972. A simple technique for demonstrating centromeric heterochromatin. Exp. Cell. Res., 75, 304-306. 